\title{
A Review on Chromite Occurrences in India-Its Genesis,Economic importance and mining issues
}

\author{
RAJU PVS ${ }^{1}$
}

${ }^{1}$ Council of Scientifc and Industrial Research-National Geophysical Research Institute, Uppal Road, Hyderabad Telangana- 500007.pvsraju@ngri.res.in

Chromite is the single commercially viable ore of chromium (Cr) which is chemically known as iron chromium oxide (Fe $\left.\mathrm{Cr}_{2} \mathrm{O}_{4}\right)$. The chromite is strategic and economically significant for country economic and industrial growth. It's a good petrogentic indicator to understand the primary magma composition and enriched secondary mineralization endowed with Titanium, Magnetite, Nickle, Copper and Platinum Group mineralization. The geology of Indian subcontinent is bestowed upon with Archean to recent ages lithounits containing chromite of commercial grade with $45-50 \mathrm{wt} \%$ $\mathrm{Cr}_{2} \mathrm{O}_{3}$. More than $96 \%$ resources of chromite are located in Odisha, mostly in Jajpur, Keonjhar and Dhenkanal districts. Minor deposits are scattered over Manipur, Nagaland, Karnataka, Jharkhand, Maharashtra, Tamil Nadu, Telangana and Andhra Pradesh. In A.P the Kondapalli-Gangineni UM Complex with Chromite lenses, pockets, bands \& disseminations with serpentinite Jannagaram-Konayyapalam layered Complex with Talc-tremolite schist with lenses of chromitite. In Karnataka Nuggihalli, Hassan with dunite, peridotite, pyroxenite, serpentite, talc-chlorite, Ti-Vmagnetite. In Tagadur, Hassan with dunite, peridotite, pyroxenite, serpentinite, talc-chlorite, Ti-V-magnetite. In Tamil nadu the Sittampundi Anorthosite Complex with hornblende-anorthosite, gneisses, chromitite, chromiferous, pyroxenite, pyroxenite, metapyroxenite \& garnet-pyroxeneplagioclase rock. In Orissa South Kaliapani is the main chrome ore mine. The hexavalent chromium, especially the friable ore is the major cause of concern as it is carcinogenic in nature. Air pollution by dumping is another major factor that leads to environmental degradation particularly during dry seasons. India is ranked fourth in global ferrochrome production. India consumes $15-30 \%$ of its production and exports the rest to countries like China, South Korea and Japan. 